\title{
Enhancing Society Civic Virtue Through Awareness of Traffic Dicipline
}

\author{
Titi Alawiyah, Dasim Budimansyah \\ Civic Education Departement \\ Universitas Pendidikan Indonesia \\ Bandung, Indonesia \\ titialawiyah@student.upi.edu,budimansyah@upi.edu
}

\begin{abstract}
In Bandung, Indonesia, traffic violations are still quite high and continue to increase every year. Traffic violations are mostly committed by adolescents. The purpose of this study is to find out how the implementation dikmas lantas program in order to foster awareness of traffic discipline in the city of Bandung as the embodiment of civic virtue. This study uses a qualitative approach with case study methods to explain the implementation of dikmas lantas program then in the city of Bandung. The subject of this research is the traffic police unit (Satlantas) Porlestabes Bandung, students and teachers of Civic Education SMK Pasundan 2 Bandung. Technic of data in this research uses observation, interview and documentation. The results of this study shows that community education programs in the field of traffic are effective to foster discipline awareness in traffic. This program must be implemented continuously in order to create the discipline of traffic in the city of Bandung.
\end{abstract}

Keywords-civic virtue; dikmas lantas program; traffic

\section{INTRODUCTION}

Traffic discipline is an endless thing to discuss. Discipline is an easy thing to say, but it is difficult to be implemented. The low discipline of traffic makes various problems occur. Whereas it should be in traffic must pay attention to many things in accordance with applicable law. The lack of legal awareness of the community has caused various cases of traffic violations to occur. Legal awareness that has been awakened in some communities we seem only a pseudo-consciousness, where the community obedient when there is a cop. But when the police did not exist, then the red light was without hesitation. Things like this that often happens in our society, especially in adolescents who tend to lack the discipline of traffic. This is very worrying and cannot be left alone. Due to the occurrence of traffic violations will result in accidents that endanger the personal soul and also the souls of others.

Based on data from the Police of Republik of Indonesia (PORLI) that the number of traffic violations is mostly done by adolescents. Based on previous research conducted by Isdendi, Rio Razab, teenage drivers are famous for unsafe and disorderly driving behavior, and a low level of awareness in traffic [1]. Data from porlestabes Bandung in 2016 there had been 21,635 violations committed by teenagers or students and by 2017 violations increased to 29,599 violations. It happened because the teenagers did not yet have emotional and ethical maturity in good driving so as to appear indiscipline in driving on the highway. Whereas adolescent's adherence to the orderly manner of traffic is one of the important things to realize the conditions of safe traffic, safe, orderly and smooth for every user of the road [2].

Lack of legal awareness in continuous traffic occurs and every year increases. It can be seen from the data obtained from porlestabes Bandung that in 2016 there had been a traffic violation of 112.005 and in 2017 increased to 150,975 violations. The number of traffic violations can be seen one of them can be seen from a traffic violation in using a helmet. Whereas in Law No. 22 of 2009 on traffic and road transport has regulated the obligations of motorists for the use of Indonesian National Standard helmet (SNI). This is in line with the results of a national interview in Thailand of 77,334 motorcyclists, conducted in 2010, identified the most common reasons for not using helmets. The most common reason $(64 \%)$ is that they travel short distances, so tend to crash. This attitude has been proven to be false by the Trauma Registry data from Khon Kaen General Hospital, which indicates that most motorcycle injuries caused by road accidents occur within 1 $\mathrm{km}$ of their homes [3].

Traffic-related accidents occur in millions of people, but are relatively unnoticed as a public issue [4]. From 2000 to 2010, motor vehicle accidents were the leading cause of death in the United States for people aged five to thirty-four, and contributed the highest proportion of first or second injury deaths in all age groups (CDCs). In addition, the World Health Organization (WHO) estimates that traffic-related deaths will be the fifth leading cause of death in the world by 2030 .

Therefore, knowledge and experience of traffic is very important to be known to every citizen. This is in line with MacDonald and Hoffmann's opinion that experienced drivers tend to stay more focused, and further ahead in the vehicle, rather than inexperienced drivers [5]. Drivers can be more focused and careful in driving so that the accident rate can be minimized.

In response to the above problems, it is necessary to have a public education in good and correct traffic by empowering the potential of existing communities, because the purpose of educational activities is not merely an educational activity, but as a pre-emotive effort (pattern of appeal and approach) in 
preventing traffic problems in the form of traffic jams, traffic violations and accidents on the road.

Based on the 1945 Constitution, Article 30 Paragraph (4) of the State Police of the Republic of Indonesia as a state instrument that guards the security and public order has the duty to protect, protect, serve the community, and enforce the law. In accordance with Article 13 of Law No.2 of 2002 on the Indonesian National Police, it is stated that the main duties of the Police of the Republic of Indonesia are: a) Maintaining the security and public order; b) Uphold the law; and c) Providing protection, protection, and service to the community. Therefore, the police have an important role in shaping legal awareness of traffic.

Therefore, Polri has a program to overcome the problem of indiscipline in traffic through the Community Education program in the Field of Traffic (Dikmas Lantas). Dikmas Then have an important role in giving understanding and understanding to the public about the traffic problems faced so that the public realizes how important the traffic in the right and proper way, which further awareness of public discipline in the traffic will become as a culture in everyday life.

Wittink Joubert, Fraser, and Sentsho argues that road safety education as a teaching skill, knowledge, understanding and behavioral pattern in traffic is essential for every citizen to reduce traffic accidents [6]. It aims to provide the experience, knowledge, thought processes, insight, and motivation needed to enable them to become safe and efficient drivers. As suggested by Juhlin and Normark that knowledge of the most common road signs should be understood as an important mode of interaction between community members in traffic [7].

Discipline is the value of a very important character in the character development of the nation. Discipline is an act that demonstrates orderly conduct and complies with various rules and regulations [8]. Traffic discipline is one reflection of national discipline that shows the dignity and self-esteem of the nation. Therefore the government should prioritize the education aspect to the community related to the discipline of traffic.

The virtue of citizenship refers to a collection of character traits that make up the emotions, attitudes and actions of the individual, especially from the way one reacts to the demands of public life. The virtues of citizens are the result of customs and practices. Virtue refers to the quality of that character built through the performance of a particular practice [9].

Thus, through the public education program in the field of traffic (Dikmas Lantas) is expected to foster public awareness of the importance of the character of discipline in traffic so as to create a good society or a society that has a virtue value.

\section{THEORY}

\section{A. Dikmas Lantas}

Community Education in the Field of Traffic Traffic public education (Dikmas Lantas) is all activities that include all efforts to foster understanding, support and active community participation in efforts to create security, safety, order and smoothness of traffic. With dikmas then this is expected to make the community to increase its participation, awareness of community law and adherence of citizen to law and legislation especially about traffic [10].

In the implementation dikmas then covers all levels of society consisting of two groups of society that is against the unorganized community (general public) and the organized community. Against the unorganized community or the general public does not have a common characteristic therefore it is necessary to set a goal and objectives that are expected to be achieved in dikmas activities such as:

- Prevent, abolish or recover anything that constitutes threats, harassment, traffic violations and accidents.

- Prevention of rapid factors and the emergence of unlawful things on the road or preventing the public from being easily influenced by unlawful things on the road.

- Improve public compliance with traffic violations.

For the general public, this dikmas program is one of the reemotive educational programs, so that in the dikmas activities then carried out is by communication that is informative, persuasive through a procedure called attention action, notice, give motivation that is encourage to receive explanation and do, apply in everyday life and dikmas then this is persuasive that is not invite to force.

The main purpose of dikmas then is to increase the adherence and awareness of the community against the things that are traffic violations in order to avoid the threat of accidents and litas by providing education as early as possible for the users of the road, so it is not wrong if the groups that should be the main target of the activity dikmas then are the students because they are very susceptible to being a newspaper accident as well as a perpetrator of violations of the law on the highway. With the awareness of all that is done is sincerity that comes out of the heart and not because of coercion so that each party both from the police and society, especially students become partners to find solutions to increase awareness of the importance of road safety. The police force in traffic as a stakeholder must be serious in implementing the dikmas program because this is not an instant good but a partnership process that must be grown from an early age, and continues as part of public education in the field of traffic along life.

\section{B. Civic Virtue}

Virtue (civility or virtue) comes from the Greek "arête" or in Latin meaning "virtues" which means perfect. People who have "virtues" are classified as good people because they have a great personality and social role. According to Dagger, a civilized or wise person not only obeys the existing social values but which shows his contribution to the long-term good [11].

Civilization (virtues) is the formation of character so it can be said that the character in a person is also the morality or civilization of the person himself. Civic virtue with individual 
rights is an essential value that balances the government and civilians promoted for the creation of a civilized society [12].

Virtue is more important than value. Virtue can be interpreted as moral or civilization rooted in the human self itself. Value (value) is very relative in defining it because it can change according to place and situation. Civic virtue with the rights of individuals is an essential value that becomes a counterweight between the government and civilians to be promoted for the creation of a civilized society. Virtue is even considered a person's moral perfection [12].

\section{Traffic Discipline}

Traffic discipline is where a person obeys what is not allowed during traffic on the road, whether in the sign or not, where the restrictions are contained in Law No. 22 of 2009 on traffic and road transport. Traffic discipline is one reflection of national discipline that shows the dignity and self-esteem of the nation. Therefore the government should prioritize the education aspect to the community related to the discipline of traffic [13].

Law No. 22 of 2009 on Road Traffic and Road Transport (LLAJ) expressly mentions aspects and objectives, namely to create safe and secure road traffic and transport, safe, orderly, and smooth. Security and safety aspects are of critical concern in traffic and road transport arrangements, therefore the LLAJ Law emphasizes the realization of ethical and cultural traffic through coaching, guidance and education of traffic from an early age and implemented through a sustainable program. There is a need for complete traffic control activities and integrated, not only with law enforcement but also efforts to be supported by all components of the nation and the active role of the whole community.

Discipline in the traffic on the individual is a form of responsibility behavior of a person against the rules or norms that apply on the highway as a manifestation of individual consciousness which is the learning process of the social environment so that the behavior of the discipline can lead to a safe, smooth and controlled traffic atmosphere. Awareness of the discipline of early traffic should begin, both within the community, school and family.

Correct traffic procedures: Every person using obligatory roads: (a) Behave in order, (b) Prevent things that may hinder, endanger the security and safety of traffic or that may cause road damage.

\section{RESEARCH METHOD}

This study uses a qualitative approach, as revealed by Sukmadinata that qualitative research is a study aimed at describing and analyzing the phenomenon, events, social activities, attitudes of trust, perception, individual and group thinking [14]. The method used is a case study to explain the implementation of public education programs in the field of traffic (dikmas lantas) in depth. This research was conducted in Porlestabes Bandung and SMK Pasundan 2 Bandung. Informants of this research is a unit of traffic police (satlantas) porlestabes bandung and students of SMK Pasundan 2 Bandung and Citizenship Education Teachers. Technique of collecting data in this research using observation, interview and documentation. Then the results of data collection obtained are analyzed through data reduction, data presentation, and draw conclusions / verification.

\section{RESULT AND DISCUSSION}

Based on the results of the research can be seen that the low traffic discipline is influenced by the lack of knowledge about how to traffic is good and right, and resulted in frequent traffic violations. With the occurrence of traffic violations can cause traffic accidents that endanger life. Weak public awareness of traffic regulations can be seen from the low level of discipline of the people in driving, thus entrenched an undisciplined attitude towards society [15]. Traffic violations are mostly perpetrated by teenagers, as adolescents do not yet have good knowledge in traffic and have no emotional intelligence yet. According to Stein, emotional intelligence is the ability of individuals to recognize feelings, reach and arouse feelings to help the mind, understand feelings and interpret them, and control feelings deeply so that it helps emotional and intellectual development [16]. Thus through public education programs in the field of traffic (dikmas), the police explain how to drive a good and true. This program focuses on teenage children so that the program is often implemented in schools. In the implementation of the police socialize how to drive good as have to obey the traffic signs, have a driver's license, vehicle registration, wearing a helmet, do not use noisy spinner and not against the current. In addition, traffic police also explain the dangers of undisciplined in traffic.

Results from interviews with students in SMK Pasundan 2 Bandung, showed that the violation of traffic $r$ because it does not know that the action is done in a violation and students do not know how the impact for himself and others. With the socialization carried out by the police regarding dikmas program then to cultivate the attitude of discipline in traffic. These activities provide an understanding of what is and should not be done in traffic, so that students can understand and apply it in everyday life. In addition, civic education teachers also have an important role in fostering student discipline in traffic. As for what it does is through integration subjects of civic education with education in traffic.

To foster discipline in traffic, of course, cooperation from various parties is needed. Factors that encourage traffic discipline include the role of the traffic police, the role of parents and the means of traffic infrastructure [17]. Dikmas lantas program are very effective in growing awareness of traffic discipline. Through this program the traffic police can work with schools or other institutions to carry out their duties in establishing proper and correct traffic awareness. so that this program must be implemented continuously because the process to instill discipline of traffic will not be maximal if only done once. SMK Pasundan 2 Bandung is a routine school every year in cooperation with traffic police to implement dikmas lantas program.

\section{CONCLUSION}

Public education programs in the field of traffic (Dikmas lantas) organized by Porlestabes Bandung can foster awareness 
of discipline in traffic. Through dikmas lantas program then Bandung people can find out how the traffic is good and correct in accordance with Law No. 22 of 2009 on traffic and road transport. Adhering to all rules in traffic can create order on the road. Discipline in traffic is also a civilization of citizenship (civic virtue) that must be owned by every society that is a reflection of good citizens. Thus this program must be implemented on an ongoing basis in order to create the discipline of traffic in the city of Bandung.

\section{REFERENCES}

[1] Isdendi, and R. Rio, Pengembangan Integrasi Pendidikan Lalu Lintas dalam Mata Pelajaran PKn melalui Media Pembelajaran Berbasis Web untuk Meningkatkan Kesadaran Hukum Peserta Didik SMPN 5 Bandung, (Tesis, Bandung, Universitas Pendidikan Indonesia).

[2] Winahyu and Anung, "Kepatuhan Remaja Terhadap Tata Cara Tertib Berlalu Lintas (Studi di Dusun Seyegan Srihardono Pundong Bantul)," Publisher, Jurnal Citizenship, vol..2, No 2, 2013.

[3] P. Jiwattanakulpaisarn, K. Kanitpong, S. Ponboon, N. Boontob, P. Aniwattakulchai, and S. Samranjit, "Does law enforcement awareness affect motorcycle helmet use? Evidence from urban cities in Thailand," Global Health Promotion, vol. 20, No. 3, 2013, pp. 14-24.

[4] C. McAndrews, "Road Safety as a Shared Responsibility and a Public Problem in Swedish Road Safety Policy," Science, Technology, \& Human Values, vol. 38, No.06, 2013, pp. 749-772.

[5] W. A. MacDonald, and E. R. Hoffmann, "Drivers' awareness of traffic sign information,” Ergonomics, vol. 34, No. 5, 1991, pp. 585-612.

[6] I. J. Joubert, W. J. Fraser, and M. L. Sentsho, "Road Safety Education: A Paradoxical State for Children in a Rural Primary School in South Africa," Journal of Asian and African Studies, vol. 48, No. 2, 2013, pp 209-228.
[7] O. Juhlin, and D. Normark, "Public Road Signs as Intermediate Interaction," Space and Culture, vol. 11, No. 4, 2008, pp. 383-408.

[8] Hasan, and H. Said, Pengembangan Pendidikan Budaya dan Karakter Bangsa", Jakarta: Kementrian Pendidikan Nasional Badan Penelitian dan Pengembangan Pusat Kurikulum, 2010.

[9] J. L. Kimpell, "Republican civic virtue, enlightened self-interest and Tocqueville," European Journal of Political Theory, vol. 14, No.3, 2015, pp 345-367.

[10] Arham, "Peran Dikmas Lantas Untuk Mencegah Terjadinya Pelanggaran Lalu Lintas", $\quad$ Retrived from https://arham44gusdiar.wordpress.com/2012/10/13/peran-dikmas-lantasuntuk-mencegah-terjadinya-pelanggaran-lalu-lintas/.

[11] R. Dagger, Civic virtues: Right, citizenship, and republican liberalism, New York: Oxford University Press, 1997.

[12] Prochaska, J. Judith, W. Miki, Rodgers, and F.S. James, "Association of parent and peer support with adolescent physical activity," Research quarterly for exercise and sport, vol.73, No. 2, pp. 206-210, 2002.

[13] Purwadi, J. Agus, and M. Saebani, "Upaya Meningkatkan Disiplin Berlalu Lintas di Kalangan Pelajar dan Mahasiswa dalam Rangka Mensukseskan Program Bengkulu Kota Pelajar (BKP)," Jurnal Media Infotama, vol. 3 No. 6, Bln 11 Th. 2008.

[14] N. Sukmadinata, Metode Penelitian Pendidikan, Bandung: PT. Remaja Rosdakarya, 2012.

[15] Sandono and Sono, Budaya Disiplin dalam Berlalu Lintas Kendaraan Roda Dua di Kota Bandung, Bandung : Universitas Telkom, 2017.

[16] Stein, J. Steven, and E. Howard, Ledakan EQ, 15 Prinsip Dasar Kecerdasan Emosional dalam Meraih Sukses (terj.), Bandung: Kaifa, 2004.

[17] Astuti, F. Ruly and I. M. Sundawa, Disiplin Berlalu Lintas di Jalan Raya pada Remaja di Desa Petak, Pacet, Mojokerto, Kajian Moral dan Kewarganegaraan, Volume 02 Nomor 03, 831-845, 2015. 